Original Article

\title{
Woody species distribution across a savanna-dry forest soil gradient in the Brazilian Cerrado
}

\author{
Distribuição de espécies arbóreas em gradiente de solo savana-floresta seca no \\ Cerrado brasileiro
}

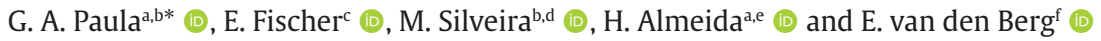 \\ aUniversidade Federal de Lavras - UFLA, Programa de Pós-graduação em Ecologia Aplicada, Lavras, MG, Brasil \\ bUniversidade Federal de Mato Grosso do Sul - UFMS, Programa de Pós-graduação em Ecologia e Conservação, Campo Grande, MS, Brasil \\ cUniversidade Federal de Mato Grosso do Sul - UFMS, Instituto de Biociências, Campo Grande, MS, Brasil \\ dUniversidade de Brasília - UnB, Programa de Pós-graduação em Zoologia, Brasília, DF, Brasil \\ eUniversidade Federal de Itajubá - UNIFEI, Instituto de Recursos Naturais, Itajubá, MG, Brasil \\ fUniversidade Federal de Lavras - UFLA, Departamento de Ecologia e Conservação, Lavras, MG, Brasil
}

\begin{abstract}
Although richness and distribution of woody species in the Cerrado physiognomies have been extensively studied, the shifts of woody species from savanna physiognomies to dry forests have not yet been addressed. Here, we investigate the effect of soil physical-chemical traits on the woody species turnover between adjacent cerrado stricto sensu and dry forest physiognomies. Woody species were surveyed, and soil and topographic variables measured, in $3010 \times 40 \mathrm{~m}$ plots systematically distributed, with 15 plots in each physiognomy. We found a spatially structured distribution of woody species, and differences of soil traits between cerrado stricto sensu and dry forest areas, mainly related to the aluminum saturation, base saturation, and available phosphorus. Aluminum saturation increased toward the savanna area, while base saturation increased toward the dry forest. Most woody species predominated in one physiognomy, such as Callisthene major in the cerrado stricto sensu and Anadenanthera colubrina in the dry forest. Only $20 \%$ of the species were widely distributed across both physiognomies or, not often, restricted to the intermediary values of the soil gradient. General results indicate that contrasting soil traits between cerrado stricto sensu and dry forest produce a strongly spatially organized and sharp transition in terms of species distribution between these physiognomies.
\end{abstract}

Keywords: aluminum saturation, cerrado stricto sensu, deciduous forest, ecotone, edaphic specialization.

\section{Resumo}

Embora a distribuição e a riqueza em espécies arbóreas nas fitofisionomias do Cerrado venham sendo bastante estudadas, a transição entre savanas e florestas deciduais ainda não foi abordada. Investigamos o efeito de características físico-químicas do solo sobre a distribuição de espécies arbóreas em região de contato entre cerrado sentido restrito e floresta estacional decidual (FED). As espécies arbóreas foram amostradas sistematicamente, e variáveis de topografia e características do solo foram medidas em 30 parcelas de $10 \times 40 \mathrm{~m}$, sendo 15 parcelas em cada fisionomia. A distribuição das espécies arbóreas foi espacialmente estruturada, e as características do solo diferiram entre as áreas de cerrado sentido restrito e FED, principalmente relacionadas à saturação de alumínio, saturação de bases e teores de fósforo. A saturação de alumínio aumentou em direção ao cerrado sentido restrito, enquanto a saturação de bases aumentou em direção à FED. A maioria das espécies arbóreas predominou em uma das fisionomias, como Callisthene major em cerrado sentido restrito e Anadenanthera colubrina em FED. Apenas $20 \%$ das espécies foram amplamente distribuídas em ambas as fisionomias ou, em poucos casos, restritas aos valores intermediários do gradiente de solo. Os resultados indicam um forte contraste de características do solo entre o cerrado sentido restrito e a FED, assim como uma transição acentuada e espacialmente organizada quanto à distribuição de espécies arbóreas.

Palavras-chave: saturação de alumínio, cerrado stricto sensu, floresta decidual, ecótono, especialização edáfica.

\section{Introduction}

The Cerrado domain contains different phytophysiognomies, varying from largely open grasslands with scattered trees or shrubs to forests with a continuous canopy stratum and shaded understory, harbouring a high diversity of plant species and life forms (Ribeiro and Walter, 2008). The most typical savanna vegetation

*e-mail: garvelino@gmail.com

Received: September 5, 2020 - Accepted: January 25, 2021 
encompasses a gradient from grasslands to woodlands, named campo limpo, campo sujo (grassy to scattered woody), cerrado stricto sensu, and cerradão (increased wood density) (Batalha and Martins, 2002; Neri et al., 2012). Densely forested habitats in the Cerrado domain also include semideciduous forests, and distinctive deciduous forests (dry forests hereafter). In addition to a marked deciduousness, dry forests show closed canopies and harbour many shade tolerant tree species with C4 grasses largely absent, whereas the savannas are mixed tree-C4 grass physiognomies with predominantly shade intolerant and evergreen tree species (Oliveira-Filho and Ratter, 1995, 2002; Lenza et al., 2015; Paiva et al., 2015). Regions where savannas and dry forests presently exist largely experienced interchanges of species through evolutionary time, which supposedly contributed for contemporary species adapted in some extent to both habitats, besides species that are distinct in each vegetation type (Bueno et al., 2016; Cordeiro et al., 2017). The last glacial period resulted in a vast expansion of the dry forests, followed by an extreme retraction throughout the present interglacial time (Pennington et al., 2000; Bueno et al., 2016). The dry forests currently constrained to small areas constitute refugia for several endemic taxa (Prado and Gibbs, 1993; Gentry, 1995; Gonzaga et al., 2016); however, they are also a topmost threatened ecosystem (Miles et al., 2006; Vieira and Scariot, 2006).

The general climate determines the vegetation types on a large scale, whereas soil physical properties and chemical composition prove an important driver of local plant assemblages (Ruggiero et al., 2002; Abreu et al., 2012; Rajakaruna, 2018). In the Brazilian Cerrado, the physiognomies of savanna have been associated to dystrophic soils, with high aluminum and low calcium availability, while dry and semideciduous forests have been associated to richer soils with low aluminum concentration (De-Souza et al., 2007; Haridasan, 2008; Kilca et al., 2009). Therefore, one can expect that soil physical-chemical traits play an important role in determining plant species distribution across adjacent areas of cerrado stricto sensu and dry forest. Moreover, a sudden or more gradual turnover of plant species is expected to depend, respectively, on how abrupt or gradual the soil properties change spatially. In this study, we describe soil physical-chemical traits and woody species turnover across the transition between cerrado stricto sensu and dry forest. We asked how much soil traits differ between the physiognomies as we empirically observed a priori an abrupt vegetation shift, and tested for effects of soil traits on woody species distribution.

\section{Material and Methods}

\subsection{Study site and data collection}

The study was carried out in the Cerrado domain, Lagamar municipality, Minas Gerais State, Southeastern Brazil. The climate is classified as Cwa of Köppen, with dry winters and rainy summers; mean annual rainfall is $1450 \mathrm{~mm}$ (Siqueira et al., 2006). The study area comprises cerrado stricto sensu on the highest lands along with vast remnants of old-growth dry forests downward on the slopes. We recorded woody species distribution and the soil gradient in a private legal reserve, with an undisturbed area of 4.5 ha $(180 \times 250 \mathrm{~m}$; the central coordinates are $18^{\circ} 10^{\prime} 03^{\prime \prime S}$ and 4652'26”W) apart from watercourses, and representative of the interface between cerrado stricto sensu and dry forest physiognomies. In this area, we uniformly distributed 30 plots of $10 \times 40 \mathrm{~m}$ distant $10 \mathrm{~m}$ from each other, resulting in a 1.2 ha of surveyed area. Departing from the observed limit between the two physiognomies, we set three lines of plots toward their interiors, arranged to contain 15 plots in each physiognomy (the spatial distribution of plots is presented along with the results of topography and soil traits. In each plot, we sampled all woody individuals with diameter at the breast height $(1.3 \mathrm{~m})(\mathrm{DBH}) \geq 3.2 \mathrm{~cm}$. We tagged the plants for control and recorded their DBH (precision $\pm 1 \mathrm{~mm}$ ) and height (precision $\pm 0.5 \mathrm{~m}$ ). For individuals with multiple branches, we measured each one and estimated one single DBH value (Scolforo and Mello, 1997). Individuals were identified or classified into morphospecies in the field, and plant material was collected for posterior identifications and inclusion in the Herbarium ESAL.

To evaluate soil chemical and physical properties, we collected eight $20 \mathrm{~cm}$-depth soil subsamples per plot. We systematically and evenly distributed the eight subsamples within the plots, and then homogenized the subsamples of the same plot resulting in a total of 30 soil samples, one per plot. Following the Embrapa protocol (Claessen et al., 1997), we evaluated texture, $\mathrm{pH}$, nutrients ( $\mathrm{P}, \mathrm{K}, \mathrm{Ca}, \mathrm{Mg}$, $\mathrm{Fe}, \mathrm{Mn}, \mathrm{Cu}, \mathrm{Zn}, \mathrm{B}), \mathrm{Al}$, available phosphorus, effective cation exchange capacity, potential acidity $(\mathrm{H}+\mathrm{Al})$, sum of bases, aluminum saturation, base saturation, and organic matter. We measured the topography with help of GPS, compass, and clinometer (cf. Carvalho et al., 2005) in 10 points per plot systematically spaced $10 \mathrm{~m}$ from each other in the plot's borders, totalling 300 points sampled in the 4.5 ha-study area.

\subsection{Data analyses}

We used a transformed based canonical redundancy analysis (tb-RDA) to test for associations between species distribution and soil traits, using the Hellinger-transformed abundance data of the woody species with 10 or more individuals in the sample (Legendre and Gallagher, 2001). We estimated the adjusted $\mathrm{R}^{2}$ for the global model, which included all soil predictor variables, and computed the p-value with a permutation test. All analyses were performed with $\mathrm{R}$ Core Team (2017) version 3.4.3. The $\mathrm{RDA}$, adjusted $\mathrm{R}^{2}$, and permutation tests were performed respectively with the functions "rda”, "RsquareAdj”, and "anova”, in the Vegan package (Oksanen et al., 2018). With the function "vif.cca" in this package, we also evaluated multicollinearity between predictor variables through the Variance Inflation Factor (VIF) (Borcard et al., 2018). We considered VIF $\geq 20$ as highly collinear, and rearranged the set of variables to decrease the redundancy when predictors reached this value. We used a distance-based Moran's Eigenvector Maps - dbMEM (Dray et al., 2006), performed with "dbmem" function in adespatial package 
(Dray et al., 2018), for modelling the effect of spatial structure in our data. With this method, spatial eigenvectors are extracted from the Euclidean distance matrix of the sample sites. The first dbMEM variables describe spatial relationships between sites in broad scale and successive eigenvectors represent subsequent finer spatial scale (Borcard et al., 2004).

To select which variables most influence the woody community we used the protocol proposed by Borcard et al. (2018). We separately computed tb-RDA for testing the effects of edaphic traits, granulometry and spatial eigenvectors on the woody community. If observed a significant effect $(\mathrm{p}<0.05)$, we performed a second stopping criterion for forward selection in which the process of inclusion of variables is limited by the adjusted $\mathrm{R}^{2}$ of the tb-RDA model. After selection of spatial and environmental variables, we performed partitioning of variance followed by a partial tb-RDA for testing the pure effects of spatial and environmental factors on the woody species distribution. We used the function "forward.sel" for forward selection in the adespatial package, and the function "varpart" for variance partitioning in the Vegan package. Finally, we spatialized the results of soil traits for the entire 4.5 ha-area using kriging method for data interpolation, with help of Surfer (Golden Software, 2002).

\section{Results}

In the 30 plots, we recorded 3038 individuals of 138 species, 51 of them with 10 or more surveyed individuals. The total number of recorded species was 95 in the cerrado stricto sensu and 94 in the dry forest plots. The contents of $\mathrm{Mg}, \mathrm{K}, \mathrm{Ca}$ were highly correlated $(\mathrm{r}>0.7)$ with organic matter (positively) and with $\mathrm{Al}$ and $\mathrm{Fe}$ (negatively). The tb-RDA performed with all nutrients presented several variables with VIF $\geq 20$. In addition, the saturation of bases and the saturation of aluminum, which represent the availability of cations ( $\mathrm{Mg}, \mathrm{K}$ and $\mathrm{Ca}$ ) and $\mathrm{Al}$ for the plants, respectively, were both highly correlated with the contents of $\mathrm{Mg}$, $\mathrm{K}$ and $\mathrm{Ca}$ measured separately. Thus, we used only the saturation of bases and saturation of aluminum along with the $\mathrm{pH}$ and the nutrients $(\mathrm{P}, \mathrm{S}, \mathrm{Mn}, \mathrm{Cu}$, and $\mathrm{B}$ ) in the final analysis; all variables presented $\mathrm{VIF}<20$ in this arrangement. The final analysis showed significant effects of edaphic traits and spatial eigenvectors, and no significant effect of soil texture, on the species assemblages. In the forward process, base saturation, phosphorus soil nutrients, and two eigenvectors for spatial structure were selected. The partitioning of variance followed by partial
tb-RDA showed a significant pure effect of soil nutrients and spatial structure (Table 1 ). The spatial structure played an important role for explaining species assemblage composition, and the shared contribution of soil and space was small (Table 1 ). The turnover of woody species was associated with the gradient of base and aluminum saturations and phosphorus (Figure 1).

The spatial variation of aluminum and base saturations markedly divided our study area in two major zones (Figure 2). The zone covered by dry forest plots presented less than $30 \%$ of aluminum saturation and more than $30 \%$ of base saturation, while the zone covered by cerrado stricto sensu showed an opposite tendency, aluminum saturation higher than $40 \%$ and base saturation lower than $30 \%$ (Figure 2 ). The intermediary values (30-50\%) of aluminum and base saturations occurred near the limit between the physiognomies. Available P, however, showed a less marked tendency across the physiognomies due to differences among some plots in the same physiognomy (Figure 2).

Most of the 51 commonest woody species recorded across the soil gradient occurred toward one of the two physiognomies, being exclusive or most common in the high-aluminum/low-base saturation or in the lowaluminum/high-base saturation part of the gradient, corresponding to the cerrado stricto sensu or dry forest plots, respectively (Figure 3). Some species, however, occurred

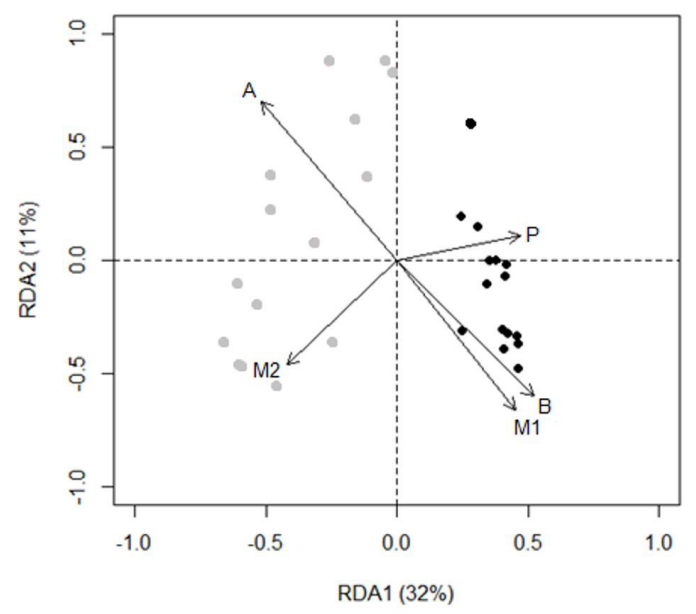

Figure 1. Biplot of tb-RDA for woody species composition, and relationships with edaphic $(\mathrm{P}=$ phosphorous; $\mathrm{A}=$ aluminum saturation; $\mathrm{B}=$ base saturation) and spatial (M1 and M2) variables, among plots in cerrado stricto sensu (gray) or dry forest (black) physiognomies.

Table 1. Edaphic and spatial variance portioning explaining the woody species composition variation across 30 plots in a savanna-dry forest transition.

\begin{tabular}{lccc}
\hline \multicolumn{1}{c}{ Fraction } & Degrees of freedom & Adj R $^{2}$ & $\boldsymbol{p}_{\text {-value }}$ \\
\hline Pure contribution of edaphic traits & 2 & 0.08 & 0.019 \\
Pure spatial contribution & 12 & 0.36 \\
Shared contribution & & 0.06 \\
Residuals & & 0.49 \\
\hline
\end{tabular}



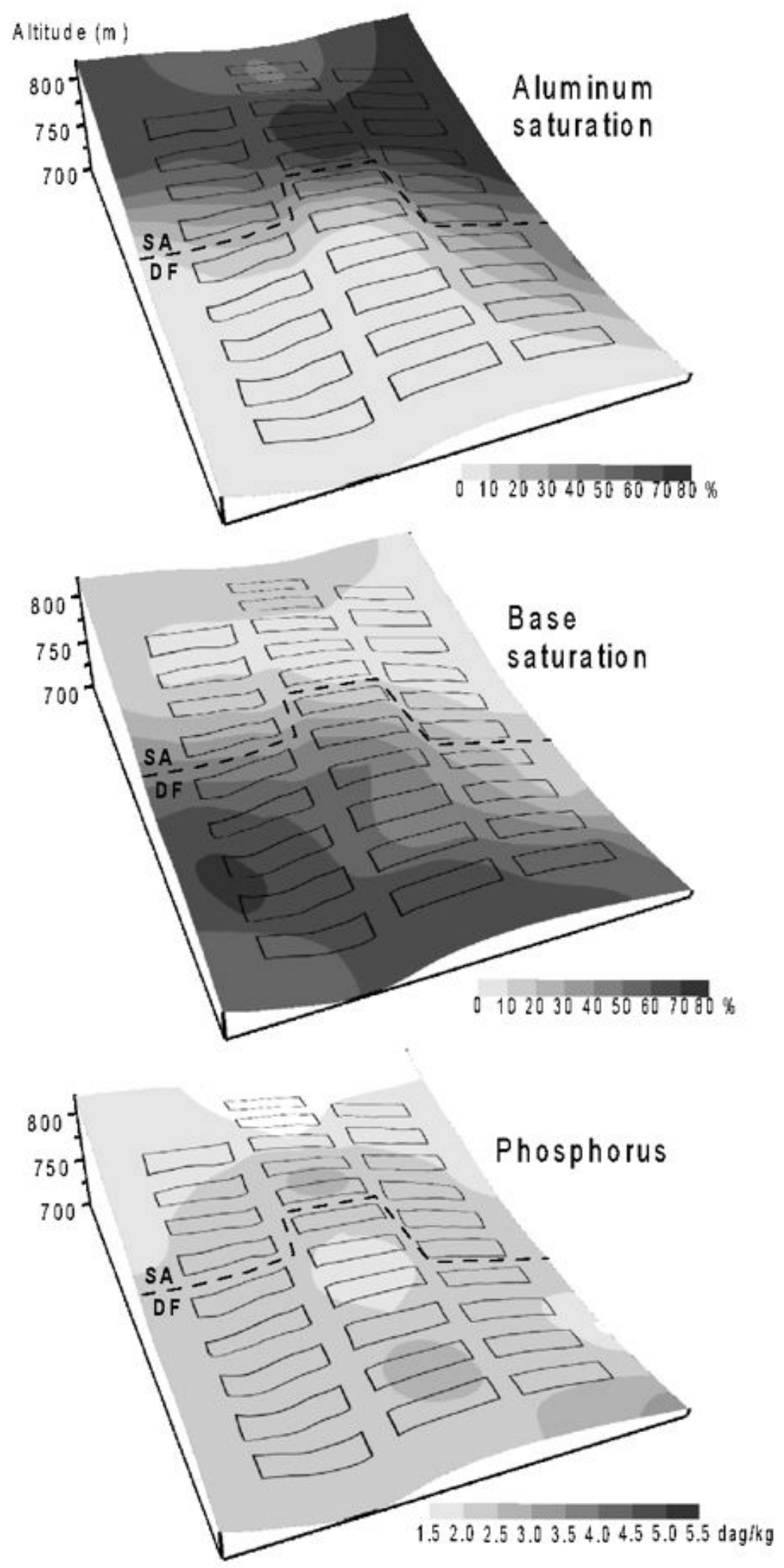

Figure 2. Topography and the gradients of aluminum saturation, base saturation, and phosphorus across 30 plots (rectangles, $10 \times 40 \mathrm{~m}$ ) in a 4.5 ha area of contact between the cerrado stricto sensu (SA) and dry forest (DF) physiognomies. 


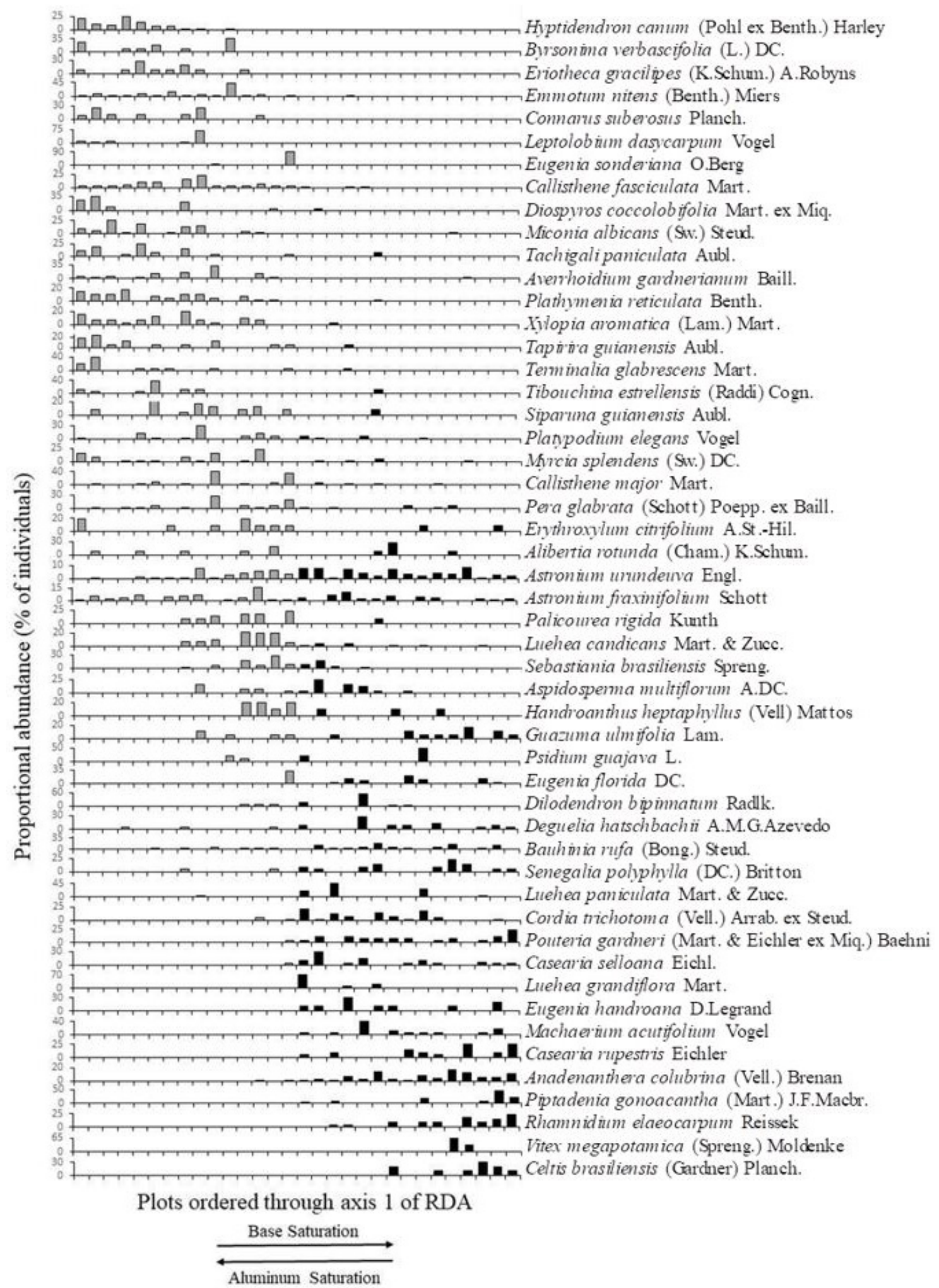

Figure 3. Proportional occurrence of 51 woody species across 30 plots ordinated by the soil gradient of aluminum saturation and base saturation (RDA axis 1, see Figure 1) in a savanna-dry forest transition. Grey and black bars correspond to cerrado stricto sensu and dry forest plots, respectively. 
either widely across the entire gradient or narrowly at intermediary values of aluminum and base saturation, in both physiognomies (Figure 3).

\section{Discussion}

Our results support a spatial structure of woody species distribution that locally separates the cerrado stricto sensu and dry forest areas, and additionally show that soil chemical characteristics consistently differ between these two physiognomies. We nonetheless found a small pure effect of soil traits on species distribution when jointly accounting for spatial effect. This outcome needs caution as our sample arrangement allowed closer plots disposed in the same physiognomy, so a redundancy of spatial distances with soil features. Indeed, soil chemical traits have proved one important factor influencing woody species composition in transitional areas between other Cerrado physiognomies (Abreu et al., 2012; Neri et al., 2012; Finger and Oestreich-Filho, 2014; but see Dantas and Batalha, 2011). Moreover, the narrow soil band with intermediary values of aluminium and base saturation outlines a sudden change of soil features, which agrees with our a priori observation of the two physiognomies and reinforces that soil features could be associated with such a discrete savanna-dry forest transition. The general results of soil composition also agree with the well-known occurrence of savanna physiognomies in dystrophic soils with high aluminium saturation and the occurrence of dry forests in fertile soils (e.g. OliveiraFilho and Ratter, 1995; Marimon-Junior and Haridasan, 2005). The contrast between the high fertility in the areas occupied by dry forest and the toxicity due to aluminium in areas occupied by the savanna probably contributes to plant specializations to different edaphic conditions (Rajakaruna, 2018; Rehmus et al., 2018).

Our dry forest plots mostly included species known to predominate in fertile soils, such as Casearia rupestris Eichler, Rhamnidium elaeocarpum Reissek and Luehea paniculata Mart. (Bertani et al., 2001; Neri et al., 2012), which in turn were rare or absent in the cerrado stricto sensu. Likewise, species common in dystrophic soils, e.g. Connarus suberosus Planch., Byrsonima verbascifolia (L.) DC., Callisthene fasciculata Mart. and Leptolobium dasycarpum Vogel (Haridasan, 2008; Kilca et al., 2009), occurred in the cerrado stricto sensu. Therefore, abundance of these species seems associated with the differences in soil composition regarding aluminium saturation, base saturation, and phosphorus at our study site. High aluminum saturation has been related to the predominance of $\mathrm{N}$-fixing legumes in the cerrado stricto sensu, which contribute to soil acidification by the increasing of $\mathrm{Al}^{+3}$ (Neri et al., 2012). However, we found a predominance of $\mathrm{N}$-fixing legume species in both, the cerrado stricto sensu and dry forest plots, even in soils with lower values of aluminum content.

Woody species in both physiognomies are often heliophytes with xerophytic characteristics (Batalha and Martins, 2002; Bieras and Sajo, 2009), which might conduct to a more gradual savanna-dry forest turnover in the absence of the soil fertility-toxicity contrast observed here. Although soil traits are an important ecological factor known to affect woody species growth and reproduction (e.g. Fischer and Santos, 2001; Wright, 2002; Kraft et al., 2008), interspecific competition is also expected to additionally explain similarities or dissimilarities of species composition between the cerrado stricto sensu and dry forests. On the one hand, soil of savanna can act as an environmental filter limiting the occurrence of species not adapted to withstand high aluminium saturation (Haridasan, 2008; Rajakaruna, 2018) and, on the other hand, occurrence of some woody species in fertile dry forest soils could depend on their competitive ability for available resources (Wright, 2002). In the absence of a major limiting environmental filter, as the aluminium toxicity in the cerrado stricto sensu, hence the interspecific competition might play an increased role in shaping relative abundances of species in the dry forest (Siqueira et al., 2009). Trees in the dry forest were taller and occurred in higher density than in the cerrado stricto sensu, which indicates a higher potential for competition between plants in the former (Tilman, 1988; Rajakaruna, 2018).

Some species were apparently unresponsive to the variation of soil conditions between cerrado stricto sensu and dry forest in our study site, such as Astronium urundeuva Engl., Handroanthus heptaphyllus (Vell.) Mattos, Astronium fraxinifolium Schott and Alibertia rotunda (Cham.) K.Schum. In fact, these species have been reported in different Cerrado physiognomies (Leite, 2002; Silva and Bates, 2002). The wide occurrence throughout the soil gradient at our study site places these species apart from those consistently occurring in one side of the gradient, cerrado stricto sensu or dry forest - e.g. Palicourea rigida Kunth and Luehea candicans Mart. that occurred toward cerrado stricto sensu, and Eugenia handroana D.Legrand and Cordia trichotoma (Vell.) Arrab. ex Steud. that occurred toward the dry forest. In addition, only Sebastiania brasiliensis Spreng., Eugenia sonderiana O.Berg, and Luehea grandiflora Mart., which are also found in semideciduous forests (Bertani et al., 2001; Cardoso and Schiavini, 2002; Naves and van-denBerg, 2012), predominated in the intermediary values of the gradient of soil composition. Thus, only few species might especially benefit from this narrow ecotonal border between our studied physiognomies, highlighting the subtle change between the cerrado stricto sensu and dry forest areas.

In conclusion, we found contrasting conditions in terms of aluminium saturation and base saturation in the transition between cerrado stricto sensu and dry forest physiognomies, and a spatially structured distribution of the woody species. Most of the commonest species differed between our studied physiognomies and only a few occurred in both. Although a direct effect of soil traits on species assemblage is expected, it was low in our analyses likely because the variation of soil conditions was entangled to the spatial distance among our samples. Finally, other dry forest enclaves in the Cerrado may present different edaphic conditions, with distinctive woody vegetation as discussed by Gonzaga et al. (2016). Further studies involving different regions of savanna-dry forest interfaces are, therefore, important for clearly understanding the main drivers of physiognomic shifts across the Cerrado. 


\section{Acknowledgements}

To Conselho Nacional de Desenvolvimento Científico e Tecnológico (CNPq) for grants to GAP (130379/2009-3), EF (06345/2019-6) and EVDB (566158/2008-6 and 307767/2008-6), and to Fundação de Amparo à Pesquisa do Estado de Minas Gerais (FAPEMIG) for grant to EVDB (CRA PPM-00274-09).

\section{References}

ABREU, M.F., PINTO, J.R.R., MARACAHIPES, L., GOMES, L., OLIVEIRA, E.A., MARIMON, B.S., MARIMON JUNIOR, B.H., FARIAS, J. and LENZA, E., 2012. Influence of edaphic variables on the floristic composition and structure of the tree-shrub vegetation in typical and rocky outcrop Cerrado areas in Serra Negra, Goiás State, Brazil. Brazilian Journal of Botany, vol. 35, no. 3, pp. 259272. http://dx.doi.org/10.1590/S1806-99592012000300005.

BATALHA, M.A. and MARTINS, F.R., 2002. Life-form spectra of Brazilian Cerrado sites. Flora, vol. 197, no. 6, pp. 452-460. http:// dx.doi.org/10.1078/0367-2530-00062.

BERTANI, D.F., RODRIGUES, R.R., BATISTA, J.L.F. and SHEPHERD, G.J., 2001. Análise temporal da heterogeneidade florística e estrutural em uma floresta ribeirinha. Brazilian Journal of Botany, vol. 24, no. 1, pp. 11-23. http://dx.doi.org/10.1590/ S0100-84042001000100002.

BIERAS, A.C. and SAJO, M.G., 2009. Leaf structure of the Cerrado (Brazilian savanna) woody plants. Trees, vol. 23, no. 3, pp. 451471. http://dx.doi.org/10.1007/s00468-008-0295-7.

BORCARD, D., GILLET, F. and LEGENDRE, P., 2018. Numerical ecology with R. 2nd ed. Cham: Springer. http://dx.doi.org/10.1007/9783-319-71404-2.

BORCARD, D., LEGENDRE, P., AVOIS-JACQUET, C. and TUOMISTO, H., 2004. Dissecting the spatial structure of ecological data at multiple scales. Ecology, vol. 85, no. 7, pp. 1826-1832. http:// dx.doi.org/10.1890/03-3111.

BUENO, M.L., PENNINGTON, T.R. and DEXTER, K.G., 2016. Effects of quaternary climatic fluctuations on the distribution of Neotropical savanna tree species. Ecography, vol. 40, no. 3, pp. 1-12. http://dx.doi.org/10.1111/ecog.01860.

CARDOSO, E. and SCHIAVINI, I., 2002. Relação entre distribuição de espécies arbóreas e topografia em um gradiente florestal na Estação Ecológica do Panga (Uberlândia, MG). Brazilian Journal of Botany, vol. 25, no. 3, pp. 277-289. http://dx.doi.org/10.1590/ S0100-84042002000300004.

CARVALHO, D.A., OLIVEIRA-FILHO, A.T., VILELA, E.A., CURI, N., VAN-DEN-BERG, E., FONTES, M.A. and BOTEZELLI, L., 2005. Distribuição de espécies arbóreo-arbustivas ao longo de um gradiente de solos e topografia em um trecho de floresta ripária do Rio São Francisco em Três Marias, MG, Brasil. Brazilian Journal of Botany, vol. 28, no. 4, pp. 329-345. http://dx.doi.org/10.1590/ S0100-84042005000200013.

CLAESSEN, M.E.C., BARRETO, W.O., DE-PAULA, J.L. and DUARTE, M.N., 1997. Manual de métodos de análises de solo. 2. ed. Rio de Janeiro: Embrapa.

CORDEIRO, L.S., ARAÚJO, F.S., KOCH, I., SIMÕES, A.O., MARTINS, F.R. and LOIOLA, M.I.B., 2017. Paleodistribution of Neotropical species of Erythroxylum (Erythroxylaceae) in humid and dry environments. Acta Botanica Brasílica, vol. 31, no. 4, pp. 645-656. http://dx.doi.org/10.1590/0102-33062017abb0053.
DANTAS, V.L. and BATALHA, M.A., 2011. Vegetation structure: fine scale relationships with soil in a Cerrado site. Flora, vol. 206, no. 4, pp. 341-346. http://dx.doi.org/10.1016/j.flora.2010.11.003.

DE-SOUZA, J.P., ARAUJO, G.M. and HARIDASAN, M., 2007. Influence of soil fertility on the distribution of tree species in a deciduous forest in the Triângulo Mineiro region of Brazil. Plant Ecology, vol. 191, no. 2, pp. 253-263. http://dx.doi.org/10.1007/s11258006-9240-2.

DRAY, S., BAUMAN, D., BLANCHET, G., BORCARD, D., CLAPPE, S., GUENARD, G., JOMBART, P., LAROCQUE, T., LEGENDRE, G., MADI, N. and WAGNER, H.H., 2018. adespatial: Multivariate Multiscale Spatial Analysis. $R$ package. Vienna: R Foundation for Statistical Computing.

DRAY, S., LEGENDRE, P. and PERES-NETO, P.R., 2006. Spatial modelling: A comprehensive framework for principal coordinate analysis of neigh-bour matrices (PCNM). Ecological Modelling, vol. 196, no. 3, pp. 483-493. http://dx.doi.org/10.1016/j. ecolmodel.2006.02.015.

FINGER, Z. and OESTREICH-FILHO, E., 2014. Efeitos do solo e da altitude sobre a distribuição de espécies arbóreas em remanescentes de cerrado sensu stricto. Advances in Forestry Science, vol. 1, no. 1, pp. 27-33.

FISCHER, E. and SANTOS, F.A.M., 2001. Demography, phenology and sex of Calophyllum brasiliense (Clusiaceae) trees in the Atlantic forest. Journal of Tropical Ecology, vol. 17, no. 6, pp. 903-909. http://dx.doi.org/10.1017/S0266467401001675.

GENTRY, A.H., 1995. Diversity and floristic composition of neotropical dry forests. In: S.H. BULLOCK, H.A.E. MOONEY and E. MEDINA, eds. Seasonally dry tropical forest. Cambridge: Cambridge University Press, pp. 146-194. http://dx.doi.org/10.1017/ CB09780511753398.007.

GOLDEN SOFTWARE, 2002. Surfer, Version 8.0. Golden, CO.

GONZAGA, A.P.D., MACHADO, E.L.M., FELFILI, J.M. and PINTO, J.R.R., 2016. Brazilian Decidual Tropical Forest enclaves: floristic, structural and environmental variations. Brazilian Journal of Botany, vol. 40, no. 2, pp. 417-426. http://dx.doi.org/10.1007/ s40415-016-0346-z.

HARIDASAN, M., 2008. Nutritional adaptations of native plants of the Cerrado biome in acid soils. Brazilian Journal of Plant Physiology, vol. 20, no. 3, pp. 183-195. http://dx.doi.org/10.1590/ S1677-04202008000300003.

KILCA, R.V., SCHIAVINI, I., ARAÚJO, G.M. and FAGG, J.M.F., 2009. Diferenças edáficas e estruturais entre duas florestas estacionais no bioma Cerrado. Neotropical Biology and Conservation, vol. 4, no. 3, pp. 150-163. http://dx.doi.org/10.4013/nbc.2009.43.05.

KRAFT, N.J., VALENCIA, R. and ACKERLY, D.D., 2008. Functional traits and niche-based tree community assembly in an Amazonian forest. Science, vol. 322, no. 5901, pp. 580-582. http://dx.doi. org/10.1126/science.1160662. PMid:18948539.

LEGENDRE, P. and GALLAGHER, E.D., 2001. Ecologically meaningful transformations for ordination of species data. Oecologia, vol. 129, no. 2, pp. 271-280. http://dx.doi.org/10.1007/ s004420100716. PMid:28547606.

LEITE, E.J., 2002. State-of-knowledge on Myracrodruon urundeuva Fr. Allemão (Anacardiaceae) for genetic conservation in Brazil. Perspectives in Plant Ecology, Evolution and Systematics, vol. 5, no. 3, pp. 193-206. http://dx.doi.org/10.1078/1433-8319-00034.

LENZA, E., SANTOS, J.O. and MARACAHIPES-SANTOS, L., 2015. Species composition, diversity, and vegetation structure in a gallery forest-cerrado sensu stricto transition zone in eastern Mato Grosso, Brazil. Acta Botanica Brasílica, vol. 29, no. 3, pp. 327-338. http://dx.doi.org/10.1590/0102-33062014abb3697. 
MARIMON-JUNIOR, B.H. and HARIDASAN, M., 2005. Comparação da vegetação arbórea e características edáficas de um cerradão e um cerrado sensu stricto em áreas adjacentes sobre solo distrófico no leste de Mato Grosso, Brasil. Acta Botanica Brasílica, vol. 19, no. 4, pp. 913-926. http://dx.doi.org/10.1590/S010233062005000400026.

MILES, L., NEWTON, A.C., DEFRIES, R.S., RAVILIOUS, C., MAY, I., BLYTH, S., KAPOS, V. and GORDON, J.E., 2006. A global overview of the conservation status of tropical dry forests. Journal of Biogeography, vol. 33, no. 3, pp. 491-505. http://dx.doi. org/10.1111/j.1365-2699.2005.01424.x.

NAVES, R.P. and VAN-DEN-BERG, E., 2012. Caracterização de uma floresta estacional semidecidual em Varginha, MG. Cerne, vol. 18, no. 3, pp. 361-370. http://dx.doi.org/10.1590/S010477602012000300002 .

NERI, A.V., SCHAEFER, C.E.G.R., SILVA, A.F., SOUZA, A.L., FERREIRAJUNIOR, W.G. and MEIRA-NETO, J.A.A., 2012. The influence of soils on the floristic composition and community structure of an area of Brazilian Cerrado vegetation. Edinburgh Journal of Botany, vol. 69, no. 1, pp. 1-27. http://dx.doi.org/10.1017/ S0960428611000382.

OKSANEN, J., BLANCHET, F.G., FRIENDLY, M., KINDT, R., LEGENDRE, P., MCGLINN, D., MINCHIN, P.R., O'HARA, R.B., SIMPSON, G.L., SOLYMOS, P., STEVENS, M.H.H., SZOECS, E. and WAGNER H., 2018. vegan: Community Ecology Package. R package. Vienna: $\mathrm{R}$ Foundation for Statistical Computing.

OLIVEIRA-FILHO, A.T. and RATTER, J.A., 1995. A study of the origin of central Brazilian forests by the analysis of plant species distribution patterns. Edinburgh Journal of Botany, vol. 52, no. 2, pp. 141-194. http://dx.doi.org/10.1017/S0960428600000949.

OLIVEIRA-FILHO, A.T. and RATTER, J.A. 2002. Vegetation physiognomies and woody flora of the Cerrado Biome. In: P.S. OLIVEIRA and R.J. MARQUIS, eds. The cerrados of Brazil: ecology and natural history of a Neotropical savanna. New York: Columbia University Press, pp. 91-120. http://dx.doi. org/10.7312/oliv12042-007.

PAIVA, A.O., SILVA, L.C.R. and HARIDASAN, M., 2015. Productivityefficiency tradeoffs in tropical gallery forest-savanna transitions: linking plant and soil processes through litter input and composition. Plant Ecology, vol. 216, no. 6, pp. 775-787. http:// dx.doi.org/10.1007/s11258-015-0466-8.

PENNINGTON, R.T., PRADO, D.E. and PENDRY, C.A., 2000. Neotropical seasonally dry forests and Quaternary vegetation changes. Journal of Biogeography, vol. 27, no. 2, pp. 261-273. http:// dx.doi.org/10.1046/j.1365-2699.2000.00397.x.

PRADO, D.E. and GIBBS, P.E., 1993. Patterns of species distributions in the dry seasonal forest of South America. Annals of the
Missouri Botanical Garden, vol. 80, no. 4, pp. 902-927. http:// dx.doi.org/10.2307/2399937.

R CORE TEAM, 2017. $R$ : a language and environment for statistical computing. Vienna: R Foundation for Statistical Computing.

RAJAKARUNA, N., 2018. Lessons on evolution from the study of edaphic specialization. Botanical Review, vol. 84, no. 1, pp. 3978. http://dx.doi.org/10.1007/s12229-017-9193-2.

REHMUS, A., BIGALKE, M., BOY, J., VALAREZO, C. and WILCKE, W., 2018. Aluminum cycling in a tropical montane forest ecosystem in southern Ecuador. Geoderma, vol. 288, pp. 196-203. http:// dx.doi.org/10.1016/j.geoderma.2016.11.002.

RIBEIRO, J.F. and WALTER, B.M.T., 2008. As principais fitofisionomias do bioma Cerrado. In: S.M. SANO, S.P. ALMEIDA and J.F. RIBEIRO, eds. Cerrado: ecologia e flora. Planaltina: Embrapa-CPAC, pp. 151-212.

RUGGIERO, P.G.C., BATALHA, M.A., PIVELLO, V.R. and MEIRELLES, S.T., 2002. Soil-vegetation relationships in cerrado (Brazilian savanna) and semideciduous forest, Southeastern Brazil. Plant Ecology, vol. 160, no. 1, pp. 1-16. http://dx.doi.org/10.1023/A:1015819219386.

SCOLFORO, J.R.S. and MELLO, J.M., 1997. Inventário florestal. Lavras: Editora UFLA.

SILVA, J.M.C. and BATES, J.M., 2002. Biogeographic patterns and conservation in the South American Cerrado: a tropical savanna hotspot. Bioscience, vol. 52, no. 3, pp. 225-233. http://dx.doi. org/10.1641/0006-3568(2002)052[0225:BPACIT]2.0.CO;2.

SIQUEIRA, A.S., ARAÚJO, G.M. and SCHIAVINI, I., 2006. Caracterização florística da Reserva Particular do Patrimônio Natural (RPPN) Fazenda Carneiro, Lagamar, MG, Brasil. Biota Neotropica, vol. 6, no. 3. http://dx.doi.org/10.1590/S1676-06032006000300010.

SIQUEIRA, A.S., ARAÚJO, G.M. and SCHIAVINI, I., 2009. Estrutura do componente arbóreo e características edáficas de dois fragmentos de floresta estacional decidual no vale do rio Araguari, MG, Brasil. Acta Botanica Brasílica, vol. 23, no. 1, pp. 10-21. http://dx.doi.org/10.1590/S0102-33062009000100003.

TILMAN, D., 1988. Plant strategies and the dynamics and structure of plant communities. Princeton: Princeton University Press. Monographs in Population Biology.

VIEIRA, D.L.M. and SCARIOT, A., 2006. Principles of natural regeneration of tropical dry forests for restoration. Restoration Ecology, vol. 14, no. 1, pp. 11-20. http://dx.doi.org/10.1111/j.1526100X.2006.00100.x.

WRIGHT, J.S., 2002. Plant diversity in tropical forests: a review of mechanisms of species coexistence. Oecologia, vol. 130, no. 1, pp. 1-14. http://dx.doi.org/10.1007/s004420100809. PMid:28547014. 